\title{
Self-Efficacy of Principal to Improving Education Quality in Era 4.0
}

\author{
Minnah El Widdah* \\ Management Education Department, Tarbiyah and Teacher \\ Training Faculty \\ Islamic State University of Sulthan Thaha Saifuddin \\ Jambi, Indonesia \\ *elwiddah01@gmail.com \\ Sukarno \\ Physic Education Department, Tarbiyah and Teacher \\ Training Faculty \\ Islamic State University of Sulthan Thaha Saifuddin \\ Jambi, Indonesia \\ sukarno@uinjambi.ac.id
}

\author{
Asep Suryana \\ Management Education Department \\ Universitas Pendidikan Indonesia \\ Bandung, Indonesia
}

\author{
Widiawati \\ Management Education Department, Tarbiyah and Teacher \\ Training Faculty \\ Islamic State University of Sulthan Thaha Saifuddin \\ Jambi, Indonesia
}

\begin{abstract}
Principals have various important roles as school leaders, moreover with the 4.0 revolution which demanded the role of more principal. This study aims to determine the level of self-efficacy of school principals as learning leaders in improving the quality of education in era 4.0 in the city of Jambi. One important role is the improvement of the quality of education. This research uses a quantitative approach by collecting data through survey methods. Measurement of the principal's selfefficacy was carried out using an instrument in the form of a four-scale education-oriented questionnaire in the $4.0 \mathrm{era}$. As for the data analysis done by the mixed method. Based on the instrument, it is obtained that $46.7 \%$ of school principals have a good level of self-efficacy to improve the quality of education in the 4.0 era, $33.5 \%$ of the medium category and the remaining 19.8 are in a low category. Therefore, it is necessary to strengthen the self-efficacy of principals, especially in the category of "medium" and "low" so that the role and function of the principal as a learning leader in the school can run more optimally so that the improvement of the quality of education in the 4.0 era is better, directed and guaranteed.
\end{abstract}

Keywords-era 4.0, principal, self efficacy, learning, education quality

\section{INTRODUCTION}

Self-efficacy is an individual's assessment of the ability or competence to carry out a task, achieve a goal, and produce something [1]. Self-efficacy is one's view of one's ability to organize and determine a job [2]. The application of the concept of self-efficacy in the workplace is known as career self-efficacy [3]. Self-efficacy is a belief about the probability that a person can carry out successfully some actions or future and achieve several results [4]. Thus it can be understood that self-efficacy is an ability (personal intelligence) that has an impact on productivity in thinking and working. Therefore, self-efficacy is one important factor for a person (including the principal) in carrying out and completing his tasks.

Self-efficacy and high motivation will support one's selfconfidence in achieving their goals and achieving high job satisfaction [5]. Self-efficacy is considered capable of predicting positive behaviour that someone will show [6]. Selfefficacy has a positive and significant effect on employee job satisfaction [5]. Self-efficacy is needed by employees to influence optimism towards career achievement in the workplace [3]. Self-efficacy fosters self-confidence, fostering positive expectations in employees. Self-efficacy can encourage employees to remain confident about their careers at work. Have peace of mind in living his career at work even with a limited career system. People who are confident in their abilities tend to succeed, whereas people who always feel like fail tend to fail. Self-efficacy is related to job satisfaction where if someone has high self-efficacy then it tends to succeed in their work thereby increasing satisfaction with what they do [4]. Self-efficacy has been identified as having a significant influence on behaviours when dealing with problems that are perceived to be poorly controlled.

The determining factor for the realization of a quality education process is the effectiveness of leadership to schools; participation and sense of responsibility of teachers, staff and other employees within the school environment; effective teaching and learning process; programmable development of teachers, staff and other employees; a curriculum that is relevant and flexible in dealing with the development of Zama; clear vision and mission and strategy; a conducive school 
climate; comprehensive assessment of strengths and weaknesses; effective communication, both internally and externally; and the involvement of parents and community [7]. This is also in line with the opinions Sonedi, Sholihah, \& Dihasbi, [8] that educational leadership takes place and takes place through activities, both carried out by the headmaster and by the teachers and administrative staff.

Learning leadership has four dimensions: (1) developing mission and learning objectives based on the mission and goals of the school; (2) managing learning; (3) improving the learning climate; and (4) developing work environment support [9]. The characteristics of leadership behaviour that can drive an effective school sustainability process include having a vision, being confident, being able to communicate ideas, being emulated, having idealism, inspiring, being able to influence and being able to appreciate differences to be transformed into a shared force, Principal-teacher- staff employees in building togetherness to realize the quality of education that is their responsibility [10].

The quality of education will be achieved if the components contained in improving the quality of education meet certain requirements. One of the components that play a role in improving the quality of education is qualified teaching staff, who can answer challenges quickly and responsibly [8]. Principals who are experienced in carrying out their main tasks, the easier it is to provide speed, convenience, accuracy, and integration in providing performance services.

The Industrial Revolution Era 4.0 was characterized by artificial intelligence, supercomputers, genetic engineering, nanotechnology, automatic cars, and innovation. These changes occur in exponential speed which will have an impact on the economy, industry, government, and politics [11]. According to Jannah [12] the existence of the industrial revolution era 4.0 can be marked by various advances in the online field. For example, mobile, smartphone, internet computerized artificial intelligence data, and robotization. Education in the era of the industrial revolution 4.0 transformed underwent various changes, one of which was the leadership style of the school principal who was asked to be adjusted to the demands of the industrial revolution 4.0 era. According to Lase [13] era 4.0, education must complement students' abilities in the academic dimension, life skills, ability to live together, and think critically and creatively. Invisible skills such as interpersonal skills, global thinking, and media and information literacy.

Principal leadership strategies that can be applied in the industrial revolution era 4.0 consist of leadership strategies oriented to improving the quality of Human Resources (HR) and supporting facilities and infrastructures in the field of Information and Communication Technology (ICT), open leadership, leadership ready to face unpredictability, leadership that reacts quickly to changes, results-oriented leadership, leadership with the $4 \mathrm{C}$ formula that is critical thinking, creativity, communication, collaboration, and leadership capable of developing an entrepreneurial spirit [14]. This is also in line with the opinion Jannah [12] that in the era of the industrial revolution, principals are required by professionals to have various competencies, as stipulated in the Minister of National Education Regulation No. 13/2007 on Principal Standards, that principals have competencies, namely: personality, supervision, managerial.

\section{METHODS}

The approach used in this study is quantitative-qualitative. The subjects in the study were 12 school principals in Jambi City, at the level of education of the Middle School (High School, Vocational School, and MA). While the object of research is the principal's leadership strategy that can be applied in the face of the industrial revolution 4.0. Measurement of the principal's self-efficacy was carried out using an instrument in the form of a four-scale educationoriented questionnaire in the 4.0 era. The data analysis is done by a mixed method with analysis activities consisting of three channels, namely data reduction, data presentation, and drawing conclusions or verification. Furthermore, to discuss data that are relevant to the topic or problem to be discussed, literature study techniques are used. A literature study is a data collection technique by finding information from literature books, journals, regulations, research reports, scientific essays, mass media, and written and electronic sources.

\section{RESULTS AND DISCUSSION}

As explained earlier, this study aims to look at the level of self-efficacy of school principals as learning leaders in order to improve the quality of education in the era of industry 4.0 revolution. Based on the data obtained through instruments that have been prepared by the research subjects, it was found that around $46.7 \%$ of school principals had a good level of selfefficacy in efforts to improve the quality of education in the 4.0 era, $33.5 \%$ were in the medium category and the remaining $19.8 \%$ were in a low category. More completely, data on the results of measuring the level of self-efficacy of principals as leaders in the learning process and in efforts to improve the quality of education in the industrial revolution era 4.0 are as follows:

TABLE I. THE LEVEl OF PRINCIPAL SELF EFFICACY

\begin{tabular}{|l|l|l|l|}
\hline No & \multicolumn{1}{|c|}{$\begin{array}{c}\text { Level of Self- } \\
\text { efficacy }\end{array}$} & $\begin{array}{c}\text { Number of } \\
\text { respondent }\end{array}$ & Percentage \\
\hline 1 & High & 5 & $46,7 \%$ \\
\hline 2 & Moderate & 4 & $33,5 \%$ \\
\hline 3 & Low & 3 & $19,8 \%$ \\
\hline & Total & 12 & $100 \%$ \\
\hline
\end{tabular}

Based to table 1 data above, it can be seen that the level of self-efficacy of principals as learning leaders in improving the quality of education in the era of the industrial revolution has not been optimal. This also shows that there are still problems that need to be investigated more deeply and sought a solution immediately. With such a condition of self-efficacy, the hope of being able to improve the quality of education in the era of the industrial revolution 4.0 can be a separate obstacle. As we 
know that the era of the industrial revolution 4.0 the challenges of education are increasingly complex, and the world (quality) of education must also adjust.

Some factors that are suspected to be the main cause of the lack of optimal self-efficacy of school principals as learning leaders in improving the quality of education in the era of the industrial revolution 4.0 are related to the low headmaster literacy, especially literacy related to this 4.0 era. This is because there is a strong relationship between the level of literacy with one's self-efficacy. This is as the result of Indrawati \& Wardono's research [15] that self-efficacy influences literacy and 4C ability. For this reason, one of the efforts that can be made to improve the quality of education in the 4.0 era is by increasing the literacy of school principals. This is in line with the opinion of Ibda and Rahmadi [16] that one of the efforts to improve the quality of education in the industrial revolution era 4.0 is through increased literacy. In addition, literacy in various fields is also believed to be able to increase the level of self-efficacy of school-head in improving the quality of education in this 4.0 era. This is also reinforced by Lase [13] that in area 4.0 there needs to be mastery of invisible skills such as interpersonal skills, global thinking, and media and information literacy.

According to Syakhrani [17], three things must be pursued by education (Islam), namely changing the old mindset that is bureaucratic rules confined, to a disruptive mindset that puts forward the corporative ways. (Islamic) education must also do self-driving to be able to innovate by the demands of the 4.0 era. Referring to this opinion, the principal with a relatively low state of self-efficacy will naturally find many obstacles and obstacles, therefore there is a need for concrete steps to upgrade the ability of the principal, especially related to literacy and self-efficacy.

In addition, the still relatively low self-efficacy of school principals as leaders in learning in order to improve the quality of education in the 4.0 era, is also supposed to have an impact on the relatively low mastery of educational problems and their ability to solve them. According to some research, self-efficacy is very closely related to the problem-solving ability, for example, research conducted by Jatisunda [18], and Putra \& Putri [19] Self-efficacy is closely related to problem-solving abilities in mathematics. Yuliyani, Handayani, \& Somawati [20] research found that self-efficacy plays a role in the ability to think positively. Considering that education in the 4.0 era was very complex, the principal's problem-solving abilities must also be improved.

Based on the conditions as described above, the government must immediately develop a system that can be run and followed by the principal so that the principal so that the principal as a leader in learning is ready for his job. For this reason, the government must be consistent in optimizing the role of supervisors and education offices to assist, encourage, and supervise school principals in carrying out their duties. Because the principal's duties include: learning systems, schools as educational units, teachers and other educators, students, and other educational facilities, government support must be in line with that. This is as stated by Aryati [21] and Yuliyani [30] that support from the government must include, 1) learning systems, 2) education units, 3) students, and 4) educators and education staff are also needed. Strengthening the four elements that exist in the education system requires a novelty movement to respond to the industrial era 4.0. With this support, it is hoped that the principal will be able to improve his self-efficacy so that he is better able to carry out his tasks, especially in improving the quality of education in the era of the Industrial Revolution 4.0

\section{CONCLUSION}

Based on the data that has been obtained and the divisions that have been carried out as described above, it can be concluded that there are around $46.7 \%$ of school principals having a good level of self-efficacy in efforts to improve the quality of education in the $4.0 \mathrm{era}, 33.5 \%$ in the medium category and the remaining 198 is in a low category. Therefore, it is necessary to strengthen the self-efficacy of principals, especially in the category of "medium" and "low" so that the role and function of the principal as a learning leader in the school can run more optimally so that the improvement of the quality of education in the 4.0 era is better, directed and guaranteed. The mastery of self-efficacy can be done by increasing literacy, problem-solving skills, and positive support from the government, education offices, and school supervisors.

\section{ACKNOWLEDGMENT}

This research was carried out by involving various parties, both those involved directly or indirectly. Therefore, the authors would like to express their deepest gratitude and appreciation to all parties involved in the research to the writing of the report and publication of the research results. Acknowledgments and high appreciation from the author to the Chancellor of the State Islamic University of Sulthan Thaha Saifuddin Jambi and the Head of the Tarbiyah and Teaching Faculty of the Islamic State University of Sulthan Thaha Saifuddin and all school principals who actively participated in this research. Hopefully, research can provide positive benefits and contributions to the development of science in the future, namely the Industrial Revolution Era 4.0.

\section{REFERENCES}

[1] M. Mastura, Hubungan Self Efficacy Dengan Kesiapsiagaan Bencana Gempa Bumi Dan Tsunami Pada Siswa Sekolah Menengah Atas Negeri 2 Dan 6 Banda Aceh. "Idea Nursing Journal”. 2015.

[2] H. Hendriana \& G. Kadarisma, Self-Efficacy dan Kemampuan Komunikasi Matematis Siswa SMP. "JNPM (Jurnal Nasional Pendidikan Matematika)". 2019.

[3] R. Valentino \& F. Himam, Efikasi Diri Untuk Meningkatkan Optimisme Terhadap Pencapaian Karir Karyawan PKWT Perusahaan X Self Efficacy To Increase Career Optimism on Employee Contract (Pkwt). "Jurnal Intervensi Psikologi". 2014. 
[4] N. Chasanah, Efficacy Dan Budaya Organisasi Terhadap Kepuasan Kerja Dalam Meningkatkan Kinerja Karyawan. "Magister Manajemen Universitas Diponegoro". 2008.

[5] I.I. Zarasara \& I. Surya, "Pengaruh Self Efficacy Terhadap Motivasi Dan Kepuasan Kerja Karyawan Inna Grand Bali Beach Hotel". None. 2016.

[6] A. Sudrajat, W. Wartonah, E. Riyanti, \& S. Suzana, Self Efficacy Meningkatkan Perilaku Pasien Dalam Latihan Mobilisasi Post Operasi ORIF Pada Ekstremitas Bawah. "Jurnal Ilmu Dan Teknologi Kesehatan". 2019.

[7] A.J. Mahardhani, M.P. Universitas, Kepemimpinan ideal kepala sekolah. "Jurnal Dimensi Pendidikan Dan Pembelajaran". 2015.

[8] S. Sonedi, T. Sholihah, \& D. Dihasbi, Peran Kepemimpinan Kepala Sekolah dalam Meningkatkan Kinerja Guru. "Anterior Jurnal”. 2018.

[9] H. Usman \& N. E. Raharjo, Strategi Kepemimpinan Pembelajaran Menyongsong Implementasi Kurikulum 2013. "Jurnal Cakrawala Pendidikan". 2013.

[10] R. Ekosiswoyo, Kepemimpinan Kepala Sekolah yang Efektif Kunci Pencapaian Kualitas Pendidikan. "Jurnal Ilmu Pendidikan”. 2016.

[11] F. Wulandari \& dkk. Kepemimpinan Kepala Sekolah di Era Revolusi Industri 4.0 dalam Meningkatkan Akreditasi Sekolah. "Prosiding Seminar Nasional Pendidikan Program Pascasarjana Universitas PGRI Palembang". 2019.

[12] L.K. Jannah, Kepemimpinan Kepala Sekolah dalam Menghadapi Era Revolusi Industri 4.0: Perspektif Manajemen Pendidikan. "ISLAMIKA". 2020.
[13] D. Lase, Pendidikan di Era Revolusi Industri 4.0. SUNDERMANN "Jurnal Ilmiah Teologi Pendidikan Sains Humaniora Dan Kebudayaan". 2019.

[14] I.W. Aryawan, Strategi Kepemimpinan Kepala Sekolah Di Era Revolusi Industri 4 . 0 Berlandaskan Pada Konsep Panca Upaya Sandhi. "Jurnal Ilmiah Ilmu Sosial”. 2019.

[15] F.A. Indrawati \& Wardono, Pengaruh Self Efficacy Terhadap Kemampuan Literasi Matematika dan Pembentukan Kemampuan 4C. "Prisma, Prosiding Seminar Nasional Matematika". 2019.

[16] H. Ibda \& E. Rahmadi, Penguatan Literasi Baru pada Guru Madrasah Ibtidaiyah dalam Menjawab Tantangan Era Revolusi Industri 4.0. "JRTIE: Journal of Research and Thought of Islamic Education". 2018.

[17] A.W. Syakhrani, Memperkuat Eksistensi Pendidikan Islam Di Era 4.0. “CBJIS : Cross-Border Journal of Islamic Studies". 2019.

[18] M.G. Jatisunda, Hubungan Self-Efficacy Siswa SMP dengan Kemampuan Pemecahan Masalah Matematis. "Jurnal THEOREMS (The Original Research of Mathematics)". 2017.

[19] H.D. Putra \& W.A.S. Putri, Kemampuan Pemecahan Masalah Matematis dan Self-Confidence Siswa SMP. "SJME (Suoremum Journal of Mathematics Education)". 2018.

[20] R. Yuliyani, S.D. Handayani, \& S. Somawati, Peran Efikasi Diri (SelfEfficacy) dan Kemampuan Berpikir Positif terhadap Kemampuan Pemecahan Masalah Matematika. "Formatif: Jurnal Ilmiah Pendidikan MIPA". 2017.

[21] S. Aryati, Tantangan perguruan tinggi di era revolusi industri 4.0. "Prosiding Nasional". 2019. 